\title{
Article \\ Financing Sustainability in the Arts Sector: The Case of the Art Bonus Public Crowdfunding Campaign in Italy
}

\author{
Chiara Carolina Donelli ${ }^{1} * *$ () Isabella Mozzoni ${ }^{2}$, Francesco Badia $^{3}{ }^{(1)}$ and Simone Fanelli ${ }^{1}$ \\ 1 Department of Economics and Management, University of Parma, 43125 Parma, Italy; simone.fanelli@unipr.it \\ 2 Department of Humanistic Studies, Social and Cultural Affairs, University of Parma, 43125 Parma, Italy; \\ isabella.mozzoni@unipr.it \\ 3 Department of Economics, Management and Business Law, University of Bari, 70124 Bari, Italy; \\ francesco.badia@uniba.it \\ * Correspondence: chiaracarolina.donelli@unipr.it
}

Citation: Donelli, C.C.; Mozzoni, I.;

Badia, F.; Fanelli, S. Financing

Sustainability in the Arts Sector: The Case of the Art Bonus Public

Crowdfunding Campaign in Italy.

Sustainability 2022, 14, 1641.

https://doi.org/10.3390/

su14031641

Academic Editors: Lucia

Marchegiani, Enrico Cori and Marc

A. Rosen

Received: 1 December 2021

Accepted: 26 January 2022

Published: 30 January 2022

Publisher's Note: MDPI stays neutral with regard to jurisdictional claims in published maps and institutional affiliations.

Copyright: (C) 2022 by the authors. Licensee MDPI, Basel, Switzerland. This article is an open access article distributed under the terms and conditions of the Creative Commons Attribution (CC BY) license (https:// creativecommons.org/licenses/by/ $4.0 /)$.

\begin{abstract}
This paper addresses the conditions that can facilitate the long-term effectiveness of civic crowdfunding fundraising strategies. While previous studies have provided a broad picture of the possible conditions for fostering effective fundraising strategies, most have considered the implications of fundraising only for management or only for cultural policy, neglecting an integrated approach that contemplates the needs of both. Thus, this work integrates cultural management and cultural policy perspectives by discussing a specific exploratory case study: Art Bonus, a cultural patronage tax incentive strategy introduced by the Italian government in 2014, which also includes civic crowdfunding features. To the best of our knowledge, Art Bonus is the first national civic crowdfunding platform supported by a national government. As an innovative and unique platform, its analysis is particularly relevant. This work analyzes the system's functioning and the results obtained in its first years of operation (2014-2016) by accessing the public database relating to the donations transited through the platform. While the initiative effectively channeled more fundraising resources into the cultural sector, the results also illustrate potential points for improving such a system.
\end{abstract}

Keywords: fundraising in the arts sector; cultural patronage; civic crowdfunding; cultural policy; cultural management; Art Bonus

\section{Introduction}

Fundraising has always been central to the sustainability of cultural organizations, especially in the nonprofit sector $[1,2]$. It enables them to overcome market constraints and supplement what is often discontinuous and insufficient public financing while simultaneously ensuring access to public goods [3]. Because of significant cuts in public funding resulting from successive economic crises and the gradual reduction of state contributions [4,5], and partly because managerial reforms have been enacted in public administration [6], fundraising has become more important in the public sector in recent years [7].

Specifically, arts and cultural organizations have become aware of the need to be more autonomous in defining their goals and implementing actions to diversify their funding sources [8,9]. Therefore, fundraising is essential, since an organization's fundraising capability is a key factor of its success, enabling its independence and sustainability $[10,11]$. In this sense, the connection between cultural organizations and sustainability is both a financial concern and an issue of socio-cultural sustainability $[12,13]$. The ability to attract a flow of financial resources that allows for the development of projects that are consistent with the institution's purposes is the best way to preserve the values that are the basis of a cultural organization and to sustain its socio-cultural and financial stability. An efficient fundraising strategy requires actions aimed at the procurement of financial resources from 
different segments of donors and through different channels, including company sponsorship; fundraising events; corporate and individual memberships; bequest fundraising; and donations from companies, trusts/foundations, and individuals [14]. From the perspective of sustainability, especially socio-cultural sustainability, not all the methods used to raise funds are equivalent. Some kinds of sponsorship, or even corporate memberships, might have to undergo certain dynamics to satisfy particular interests, linked in some way to market or economic return logics $[15,16]$. Therefore, a successful fundraising strategy is not only connected to the amount of funding resources obtained, but also to an organization's ability to discern the best funding channels to ensure the organization's cultural sustainability. Consistently, effective fundraising is important for cultural management, and implementing fundraising strategies that appeal to individual $[17,18]$ and corporate donors $[19,20]$ has become a key theme in the literature. Analysis of the donors' motivations is a central issue in the field of fundraising because such donations are a key strategy for maximizing private giving [21,22].

The discussion about fundraising is also relevant in the field of public policy, linked to the capacity of development and the implementation of measures able to increase the level of donations that communities make to the nonprofit sector, fostering donors' loyalty and motivation $[23,24]$. This is possible through the realization of appropriate legal and fiscal systems [25], concepts that are also relevant in the field of cultural policy [26], where some research has emerged about the potentialities of tax incentives to stimulate the growth of financial contributions that private individuals make to cultural institutions $[27,28]$.

The existing literature examines fundraising and its implications in the field of cultural policy and management, but these two perspectives are not integrated, and the framework appears to lack detail. The present work aims to fill this gap, combining the two perspectives to offer a viewpoint that is useful for both managerial and policy applications according to an integrated vision of fundraising in the cultural field. Specifically, the work focuses on crowdfunding, a tool that can be related to fundraising in terms of both cultural policy and management.

Although some form of crowdfunding was used before the diffusion of the internet [29], crowdfunding can generally be perceived as an emerging phenomenon based on the spread and development of informal and information technologies [29,30], especially in arts and culture [31]. Crowdfunding consists of a form of micro-financing that generally aims to collect small amounts of money from a large number of donors and uses the internet as its field of action [32]. It is thus not only a way to finance arts and culture, but it is a "collective effort" of several individuals who decide to pool their resources to jointly collaborate to achieve the mission [30].

Enhancing opportunities for crowdfunding in the field of culture is the task of both policy makers and managers. Moreover, accurately studying crowdfunding opportunities could be particularly interesting from the perspective of sustainability [33] because the basic conditions for a successful crowdfunding campaign (a high number of donors, each making a small donation) could represent a way to guarantee the independence of the funded project and thus its socio-cultural sustainability. At the same time, the connection between sustainability and crowdfunding is also important in terms of designing and implementing crowdfunding projects and platforms that are financially sustainable [34].

Starting from these premises, this work uses the perspective of exploratory [35] casestudy research [36] to examine an innovative fundraising tool, Art Bonus, set up by the Italian national government in 2013 and operational since 2014. Art Bonus consists of strong fiscal incentives to private individuals who make donations to public cultural institutions and a government website that aims to invite individuals and corporations to make donations and encourages them to do so. Art Bonus was set up to enhance new models of public-private collaboration in financing Italian public cultural heritage based on the public profile and commitments of potential donors.

Art Bonus appears to be consistent with a specific kind of crowdfunding, civic crowdfunding, where citizens collaborate with governments to fund projects that meet public 
needs [35,37]. Art Bonus is particularly interesting because, to the best of our knowledge, it is the first application of a national civic crowdfunding platform supported by a national government on an ongoing basis. In this work, the case is discussed by conducting a deep analysis of the system's functioning and the results obtained by the platform in its first two years of operation (2014-2016) by accessing the public database containing data relating to the loans transited through the platform.

The paper is structured as follows: Section 2 presents a review of the literature on topics relevant to private funding for cultural organizations from the viewpoints of cultural management and policy. These two perspectives are then integrated, and details about crowdfunding and the key factors of a successful fundraising strategy from the perspectives of cultural management and cultural policy are outlined. In Section 3, the case of Italy is analyzed in detail, and the Art Bonus scheme is presented. In Section 4, the preliminary results of the scheme are analyzed empirically. Section 5 presents the discussion and the implications for management. Section 6 presents the conclusions. Finally, Section 7 presents the research limitations and suggests possible lines for future research on this topic.

\section{Literature Review}

\subsection{Fundraising in the Arts}

Fundraising is essential for expanding revenue streams from non-governmental sources [38] for the management of any kind of nonprofit organization. This is particularly true for organizations that aim at preserving and promoting the arts and cultural heritage or activities [8]. For organizations that do not depend solely on commercial revenue, their fundraising capability is a key factor in their success [11]. In many countries, the arts sector is far from being financially stable, and the viability of organizations is often threatened because insufficient resources have a negative impact on the artistic vibrancy and public accessibility of the arts heritage. Thus, it becomes necessary for arts organizations to find alternative forms of funding for culture-related projects and activities [39], and the private sector contributes as an important revenue stream for the protection and enhancement of the cultural sector [40], especially during crises [5].

Studies on fundraising primarily focus on two areas [25]. Some motivational studies focus on the reasons for donations and the consequent management choices that favor and promote a more incisive fundraising strategy. Other studies focus on the governmental policies that support cultural organizations or the institutions responsible for cultural heritage or activities.

\subsubsection{Managerial Initiatives to Foster Fundraising: Motivational Studies}

A specific point of interest for management studies is the analysis of what makes fundraising strategies more effective. The two segments, individual donors and corporate donors, have different motives. For individual donors, eight possible factors that drive charitable giving have been identified [17]: awareness, solicitation, cost and benefit analysis, altruism, reputation, psychological benefits (joy of giving and self-image), personal values, and usefulness. Corporate philanthropy can be regarded as being strategic for business [20]. This is because economic factors, such as marketing (brand image) and legitimation [15,41], drive a company's decision to support nonprofit institutions. Corporate tax returns also play a key role [42].

Bertacchini et al. [21] analyzed donor motives in the field of supporting cultural heritage. They defined three kinds of motives: intrinsic, arising from personal feelings and convictions; extrinsic, caused by economic factors; and reputation, connected with an individual's need for social recognition. Other researchers have shown that, in the performing arts, season ticket-holders are more willing to donate than non-subscribers [43], so increasing the number of season tickets sold appears to be a good fundraising strategy when the nature of the cultural activity allows it.

Donors can be persuaded to donate by perceiving different forms of legitimacy: pragmatic legitimacy, where they perceive the nonprofit institution as being beneficial, and 
moral legitimacy, where they feel a sense of "doing the right thing" [44] or co-creating social value [45]. Moreover, donors can be encouraged to donate by low "donation prices" (i.e., the cost of fundraising campaigns) and low information costs (i.e., the costs incurred by the donor to ascertain the soundness of a fundraising campaign) [46].

\subsubsection{Government Initiatives to Foster Fundraising: Cultural Policy}

As noted above, the development of an effective fundraising system is an area of interest in the fields of cultural policy and cultural management [47]. Public funding of the arts has long been considered to be a tool for economic and social modernization, thanks to the positive impact of the arts on the economy and the business environment $[39,48]$. In fact, culture can be considered a merit good, capable of having a beneficial effect on society as a whole [49].

The development of appropriate fundraising strategies has been studied for at least 40 years in countries with a consolidated tradition of private donations to charities and nonprofit organizations, like the United States (US) and the United Kingdom (UK) [17]. In mainland Europe, the private and philanthropic funding practices are different from those in US, and making donations is less widely practiced [50]. Cuts in public funding have also necessitated new neo-liberal strategies for diversifying funding in the arts, and in various countries, tax incentives for corporations and individuals and new private funding incentive programs have been introduced. These include Mécénat Culturel in France, Art Bonus in Italy, and the Gift Aid Scheme in the UK $[25,28]$. For management, the starting point is to identify the factors that encourage donations and then to create strategies tailored to different donors $[15,21]$. This implies continuous dialogue with key stakeholders to identify and match their expectations [51] and building trust through the efficacious use of the donations received [52].

In the current context of public funding cuts due to the crisis of the traditional welfare state and the economic crises $[4,53]$ unleashed by the 2008 financial crisis and the recent COVID-19 pandemic, the role of effective cultural policies $[40,54]$ in encouraging private rather than public funding has become essential [5]. In terms of public policy, potential donors can be given advantages and incentives, such as tax exemptions, deductions, rebates, and credits. The literature reports four main functions of taxation law [55]: supporting the nonprofit sector through tax relief, supporting equity through the redistribution of resources, regulating the behavior of nonprofit managers, and a border-patrol function guaranteeing that distinctions between the nonprofit sector and the commercial and governmental sectors are clearly demarcated.

Different fiscal incentives for donations and government administrative systems have a significant impact on the patterns of philanthropic giving and the volume of donations. Comparative studies across different countries reveal that there are numerous different national tax policies [56,57] in their respective arts and culture sectors [5,27,28]. Moreover, local, state, and federal governments have started exploring the potential of crowdfunding to transform the conventional financing methods previously used to fund public projects and services $[58,59]$.

\subsection{The Emerging Role of Crowdfunding}

This section first focuses on crowdfunding, which can be analyzed both in terms of the cultural institutions that run a campaign and the policy makers who intend to encourage fundraising. Crowdfunding, defined as the raising of funds in the form of relatively small donations or investments from a large number of individuals [32], is not a totally new concept in the field of fundraising. However, the term has become widespread in its modern meaning, in which an internet-based platform is central [37]. These platforms exploit the potentialities of affordable online payments, and they make it possible for users to connect with a wide audience, including in the arts and cultural sector [60].

Crowdfunding draws inspiration from concepts such as micro-finance [61] and crowdsourcing [62], leveraging the internet to fund a diverse range of projects through relatively 
small contributions from a relatively large number of individuals without traditional financial intermediaries. Crowdfunding in the arts has traditionally been used to finance creative and entrepreneurial projects in the private sector [63]. This is becoming more and more important due to cuts in public funding in ensuring the public's access to the arts while keeping prices under control. Furthermore, crowdfunding is a new way of collaborating, resulting in new behaviors between the funders and the recipients [29].

Crowdfunding has also been used to finance nonprofit and innovative entrepreneurial activity in the public sphere, engaging a wide audience of potential donors in exchange for different types of rewards, including equity-based crowdfunding [63] and access to governance. According to Drucker [64], philanthropy is not only about raising funds; it is also about people development. Thus, crowdfunding is a way to encourage wider democratic engagement in the arts, differing from the philanthropy of major donors. Crowdfunding campaigns can be categorized into two groups based on the motivation of the funders $[32,63]$. It can be donation-based, which is the case for the reward model, or investment-based, as in the equity, debt, and royalty models [34]. In the investment-based model, there is the need to develop appropriate incentives, in addition to financial ones, for allowing borrowers to access additional benefits [30].

In donation-based models, a specific kind of crowdfunding, civic crowdfunding, is emerging, where citizens collaborate with government to fund projects to meet public needs $[37,38,65]$. Donation-based models are based on pure donation by the funders, who do not expect anything in return; thus, this is a crowd micro-mecenatism, which previous research has shown to be more attractive for donors in the cultural heritage sector [29]. This type of crowdfunding is especially interesting because it refers to organizations that are more willing to operate under non-market rules [47].

There are some characteristics of crowdfunding that differentiate this tool from other forms of private funding for public and nonprofit organizations, such as sponsorship or public-private partnerships (PPPs):

1. Unlike sponsorship, private and corporate donations do not require an economic return in terms of visibility, avoiding the risk of potential commercial exploitation of the public heritage and ensuring the possibility for arts managers to better place the amount received to ensure delivery of the organization's mission [16,66]. Indeed, the recipient cultural organization has no formal obligation to the donors, as the exploitation of cultural heritage is one of the main conditions of the enhancement of the historical-architectural heritage, with the risk of the progressive transformation of monuments into banal support for advertising [15]. Donors in crowdfunding platforms are attracted from the possibility to effectively contribute to the creative process and engage with the organizations.

2. Through crowdfunding, possible democratization of the form of financing for the cultural organization encourages a participatory [65] and more democratic process in which anyone can contribute [18] and which is based on trust [30]. This practice could help organizations to overcome problems related to decreases in public financing and the inability for public administrations to effectively valorize, protect, and promote arts and cultural heritage [29].

3. Potentially, crowdfunding could also leave room for innovation and experimentation while minimizing the risk of unethical practices or sponsor-seeking behavior $[16,67]$. The democratization also involves the cultural organizations, as it encourages bottomup initiatives from small organizations that might not have the resources they need to start their own fundraising campaigns $[47,68]$. In addition, crowdfunding provides an impetus for collaboration that could speed up the financing of business projects while also requiring new sets of behaviors by the various actors. This process could result in major changes in relationships between investors and those who receive funding, creating a field where more solid participatory relationships with audiences are strengthened, as well as a sense of shared ownership of shared heritage $[29,69]$. 
Crowdfunding has traditionally been used by the private sector; however, today, an increasing number of public entities have begun exploring its potential and transforming conventional methods of financing public projects and services $[33,58]$. Crowdfunding, especially civic crowdfunding, which links public policy with the initiatives of individual organizations toward a common purpose of financing and development, is particularly suitable for the integrated study of successful fundraising strategies from both cultural policy and cultural management perspectives.

An Integrated Perspective for Studying Crowdfunding in the Arts

An analysis of the literature showed that an effective system of fundraising in terms of cultural management and policy should include the following strategic factors:

1. A close relationship with the local community of the cultural institution [70] in order to maximize the personal motivation of patrons connected to their cultural capital [26,71];

2. A system of compensation for donors, which might range from a feeling of gratification to real involvement in the organization and activities of the recipient institution [29,72-74], and economic advantages, such as fiscal incentives [27,28];

3. An open and accountable flow of communication toward potential donors [75] based on explicit requests for donations [76], preliminary specification of the activities that will benefit from donor contributions [77], complete transparency about the expenses connected with the contribution, and the results of the activities supported by the donations [78].

Developing these three key factors should be the goal of cultural organization management and policy makers when creating the conditions to encourage cultural institutional fundraising.

Although crowdfunding traces its roots to donations, it is different from general fundraising activities as both approaches have different motivations and practices [59]. Research on reward-based crowdfunding and the arts is still limited. The most recent research focusing on a specific type of crowdfunding campaign to fund appropriate technology in the arts suggested that a user's intentions to donate include social influence, effort expectancy, and perceived trust [59]. Previous research on crowdfunding has investigated whether the content and orientation of reward-based crowdfunding affect the final outcome and sustainability of the project [79], but it is necessary to focus on this issue in the field of the arts.

This paper studies the case of a fundraising campaign, classifiable as civic crowdfunding, to verify the presence and validity of the three conditions outlined above. The campaign, Art Bonus, was introduced by the Italian government in 2013 to promote and increase private fundraising for public cultural organizations. Considering three factors, a close relationship with the community, implementation of a proper compensation system, and open and accountable flow of communication, the following research questions were formulated:

1. Which of the three key factors for a successful fundraising campaign can be applied to a civic crowdfunding campaign in the arts sector?

2. What indications does a civic crowdfunding campaign in the arts sector provide for the development and enrichment of the theory on these key factors?

\section{Materials and Methods}

The Art Bonus scheme came into effect in Italy on 1 June 2014. The data analyzed in this paper covers a time period longer than one year in order to capture the effects of the reform and identify implications for the management of cultural organizations. We collected and analyzed data on donations made under the Art Bonus fiscal rebate from 1 June 2014 to 30 September 2016. Art Bonus was analyzed in the first two years of its application, from 2014 to 2016, to understand the implications of its introduction. 


\subsection{Research Context: The Art Bonus Scheme}

Fundraising can be carried out in a multitude of ways reflecting the wide variety of sociocultural contexts, cultural heritages, economic difficulties, fiscal backdrops, conceptions of the role of the individual and community, and charitable organizations; furthermore, methods of fundraising have been professionalized. The study discussed in this paper focused on Italy, which is a clear example of a system undergoing substantial reforms in the private financing of culture. It introduced an innovative system for encouraging corporate and private donations to public cultural organizations.

The rich Italian cultural heritage and its institutional system are largely managed and owned by the state. Traditionally there has been a high level of governmental spending and a low degree of financial independence for the management of cultural institutions. However, the reduction in public funding in recent years has made it necessary for cultural institutions to use self-financing. The government's response to this necessity was Law Decree no. 83 of 31 May 2014 (Culture Decree converted into Law no. 106 of 29 July 2014), which introduced a new set of rules to encourage private donations to support culture and the arts. Art Bonus is one of the most significant tax-related measures; as a scheme for a tax credit of $65 \%$ of the donation, it provides a free-of-charge platform to connect donors and recipients. This measure was intended to enhance new models of public-private collaboration in financing Italian public cultural heritage, starting from the fiscal year of 2014. Art Bonus abrogates the previous tax rebate for private donations (TUIR Article 15, Commas1 $\mathrm{h}$ and I, as well as Article 100 Commas $\mathrm{f}$ and $\mathrm{g}$ ). Companies can claim tax credits for up to $0.5 \%$ of their annual revenues; for individuals, the cap is set at $15 \%$ of their annual taxable income. The tax credit is only granted for monetary donations made to public entities or a concessionaire of public cultural assets.

The scheme allows for three types of donations:

1. Area A: Maintenance, protection, and restoration of public cultural assets. Donations in this area are related to a specific asset and clearly defined projects.

2. Area B: Support for public cultural institutions (e.g., museums, libraries, archives, archaeological sites and parks, monuments, concert and opera houses, and theatres, etc.), with specific references to the operational activities of performing arts institutions. This includes more generic donations in support of current operations and the ordinary activities of cultural institutions.

3. Area C: Restoration and development of public theatres and auditoriums. As in Section A, the donations are related to a specific asset, but here, they are limited to public theatres and auditoriums.

Recipient institutions are required to report the donations to the Italian Ministry of Culture (Mibac) every month and publish the sums received and spent on the Mibac website and their own website. Donations under Area A and Area $\mathrm{C}$ are counted as capital expenditures; thus, they are subject to budget constraints. Donations under Area B, in support of places of culture, opera houses, and theatres, fall under operating expenditures; they are not subject to budget constraints.

Mibac has a dedicated free-of-charge website supplying comprehensive information. For potential donators, the donating procedure is outlined, and the recipient organizations are listed. There is information on the project to be financed and the amount of funding requested and received and general information on the institutions. For organizations soliciting donations, the website supplies information on regulations and about patrons and donors (who they are and how much and to which institutions they have donated). This information is made public only where the donor has given permission to publish personal data; otherwise, the website only shows the amount donated and the recipient organization. The platform is similar in structure to a crowdfunding website, bringing together project owners and potential backers, facilitating information flow and transactions [80]. The system appears to follow the donation-based model of crowdfunding, typically used for artistic or humanitarian projects, which places the funders in the position of philanthropists 
who expect no direct return for their donations except for recognition in terms of visibility. However, donors are rewarded for their effort through tax credits or visibility recognition.

\subsection{Research Design}

This research adopted an exploratory case-study approach [36,81], using a longitudinal perspective to address how the introduction of a new public crowdfunding platform impacted private donations to public heritage. The uniqueness of the case lies in the fact that Italy implemented reforms based on tax breaks along with an experiment in civic crowdfunding through a platform owned and managed by the government and operating directly within the public sector.

The present case study compared historical data and recent data extracted by the authors from the ministerial open-access website for a two-year period following the implementation of the reform (1 June 2014 to 30 September 2016). This approach enabled a detailed interpretation of the effects of the recently implemented reforms. As noted by Merriam [82], case studies are particularly suited to the analysis of transitional processes that involve causal explanation.

\subsection{Data Collection}

The results are presented in two sections connected to the two literature streams described above:

1. A description of the results with specific reference to the three areas of intervention identified by the law.

2. An analysis of the results based on the three factors identified in the literature as being important areas of interest.

The first section presents an overall description of the general results of Art Bonus in comparison to historical data on public cultural organizations, as well as data describing the three areas, A, B, and C, defined by the reform. Classifications of the types of cultural assets were drawn from the UNESCO framework for cultural statistics [83] and adapted to Art Bonus. Historical data are based on previous publications of charitable donations, analyzed by the Italian Association Civita [84] and financed by the European Union [85].

Data describing the three areas of analysis were extracted by the authors directly from the Mibac website artbonus.gov.it (the civic crowdfunding platform), which, on a daily basis, registers the increase in the financial resources that each recipient cultural organization has collected and the name/type of donors.

The second section interprets the data extracted from the platform and the impact of Art Bonus with reference to the three aspects emerging from previous literature. These aspects are important for developing an effective managerial strategy to attract financial resources for cultural activities $[25,86]$. Doing this analysis, the following questions were addressed to identify the pattern of donations:

- Who donates and at what level?

- Why is a donation made?

- What do the patrons finance?

The first aspect, considered strategic for management, was defining the profiles of the donors [87]. Thus, an analysis of patrons was conducted to identify the types of donors (individuals, companies, banking foundations, or nonprofit organization) and the donations made.

The second aspect was to determine what stimulates a donor's willingness to donate. Empirical literature showed that the main motives for donating were a sense of civic duty and belonging to a community $[21,26,73]$. Consequently, a link between the cities or geographical areas hosting the recipient organization and donor can be hypothesized.

The third important step was establishing to which organizations the donors contributed. From a managerial perspective, it is important to understand whether donors prefer specific financial projects or the overall activities of an organization $[23,43]$. Thus, 
we compared the amount of funds raised in Area A and Area C of Art Bonus, where the precise intervention to be supported is indicated, with the amount of funds raised in Area $\mathrm{B}$, which are for overall support.

The findings served to identify the implications for the management of cultural organizations. These ideas are discussed in more detail in Section 5: Discussion and Implications for Management.

\section{Results}

\subsection{Art Bonus Results in Terms of Cultural Policy}

In the period under study (June 2014-September 2016), a total of $€ 123,261,089$ was collected through the Art Bonus scheme, subdivided as follows: 50.4\% in Area A $(€ 62,164,315)$, $49.5 \%$ in Area B $(€ 60,957,373)$, and $0.1 \%$ in Area C $(€ 139,400)$.

There were 764 fundraising campaigns. Area A accounted for $75.0 \%$ of these, and the categories of cultural assets that received the most funds were museums, followed by monuments and ancient buildings and theatres (21.1\%). Figure 1 shows the types of cultural assets that were funded.

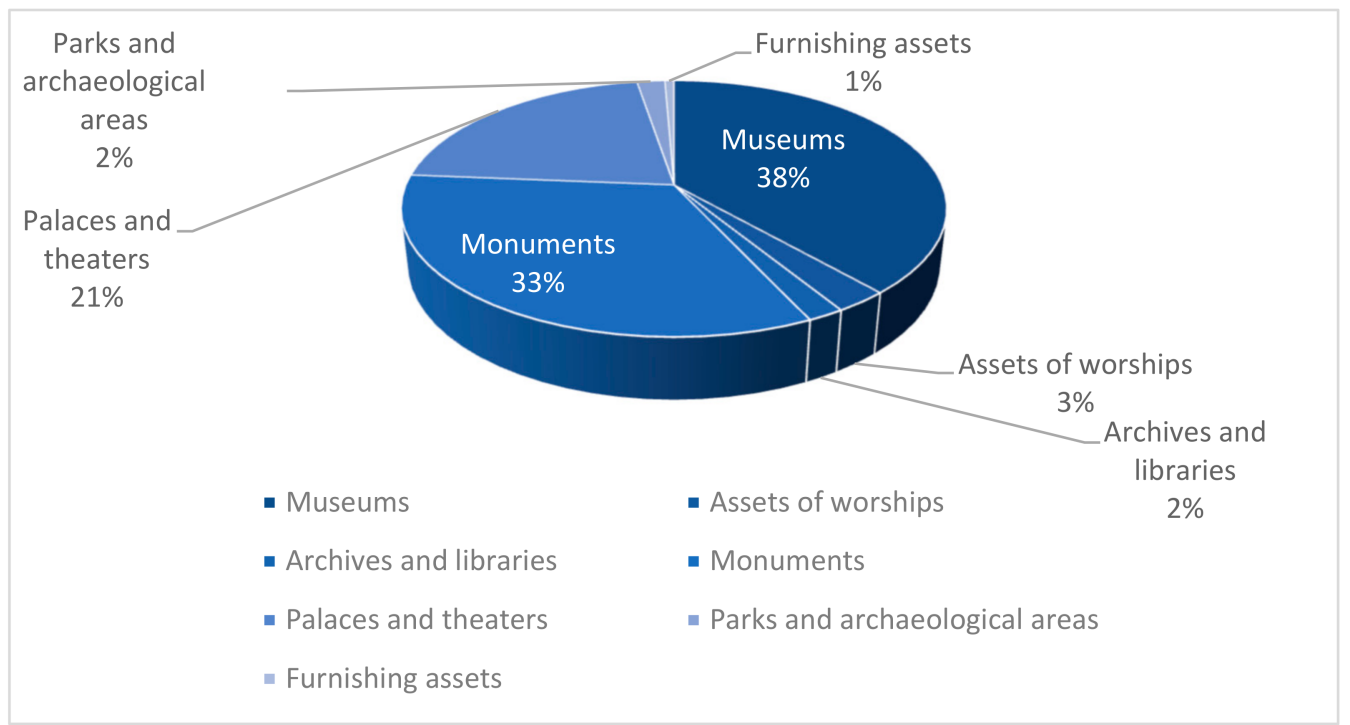

Figure 1. Donations received in Area A by type of cultural asset.

In Area B, as shown in Figure 2, 181 cultural organizations launched fundraising campaigns, accounting for $24 \%$ of the total fundraising efforts under the Art Bonus project. In this area, the most funded heritage projects were theatres $(96.2 \% ; € 58,478,418)$ and, in particular, theatre foundations.

Although Area B received 1370 donations for a total of $€ 60,957,373$, almost all of those donations went to theatres and foundations. Notably, this trend was anticipated by the legislators who mentioned a specific interest in financing the operational activities of performing arts institutions. Indeed, in Italy, as in other countries [88], the performing arts sector, which is small, is struggling to achieve financial stability and cover its operational expenses [89].

Finally, Area $\mathrm{C}$ was the smallest in terms of both the number of organizations involved and the number of donations made. In fact, only 10 public theatres and auditoriums used fundraising campaigns in Area C, and just five of them received donations, for a total of $€ 139.400$.

Thus, the recipient organizations could be grouped into two main categories: campaigns for specific projects (maintenance, protection, and restoration) for cultural public heritage and institutions (Area A and Area C) and campaigns for operational activities that 
mainly focus on performing arts institutions (Area B), hereafter termed cultural heritage institutions (Area A and Area C) and performing arts institutions (Area B).

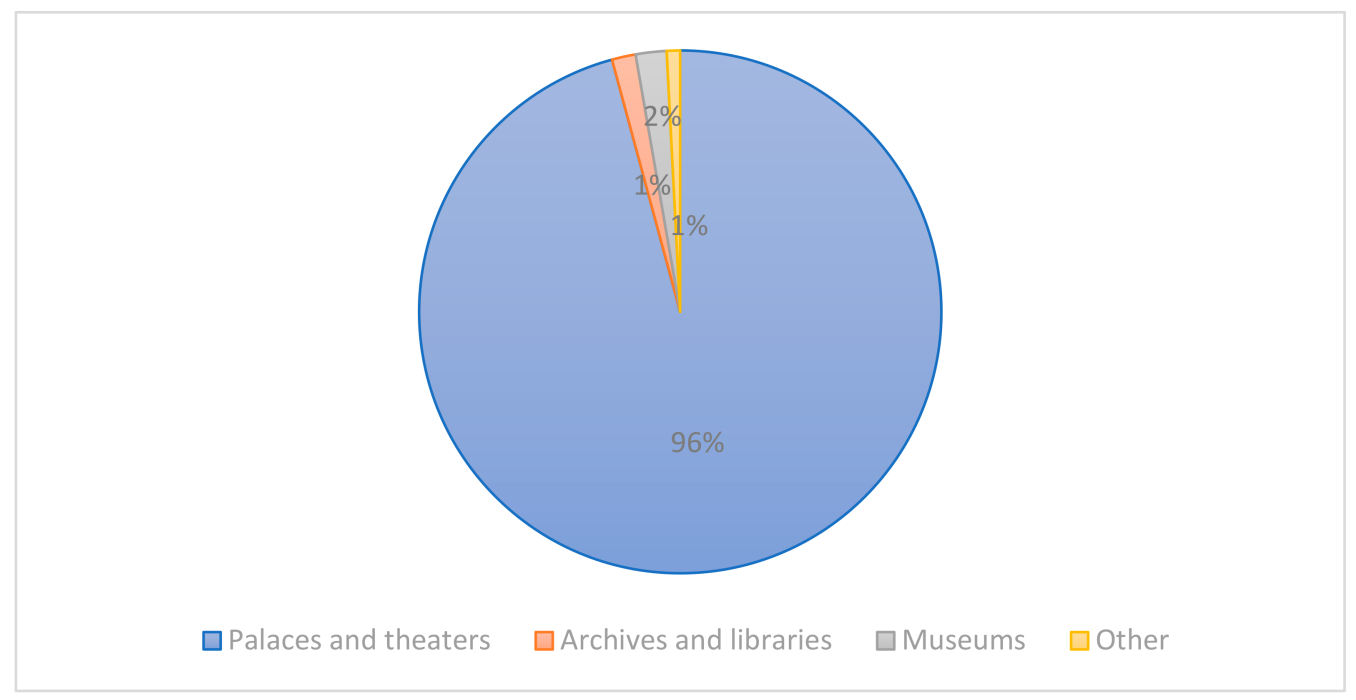

Figure 2. Donations received in Area B by type of cultural asset.

Performing arts institutions have traditionally received more attention from the private sector, as they are more widely distributed throughout Italy and are representative of traditional heritage, as confirmed by historical data (2007-2008). During the two years following the Cultural Decree, the opposite trend was observed, with cultural heritage attracting $22 \%$ more funding than performing art institutions ( $€ 62,303,715$ vs. $€ 60,957,373)$. Table 1 presents a comparison of the amounts donated to performing arts institutions and cultural heritage, pre- and post-reform. Two years after the introduction of Art Bonus, the number of donations increased by $64 \%$, the amount donated almost doubled $(+94 \%)$, and the average donation increased by $16 \%$ (Table 1 ).

Table 1. A comparison of pre- and post-reform donations. (Sources: Civita [84] and the present research).

\begin{tabular}{ccccc}
\hline & \multicolumn{2}{c}{ Years 2007-2008 } & \multicolumn{2}{c}{ Years 2014-2016 } \\
\hline & No. of Donations & Amount Donated $(\boldsymbol{\epsilon})$ & No. of Donations & Amount Donated $(\boldsymbol{€})$ \\
\hline Cultural Heritage & 1375 & $24,475,272$ & 1788 & $62,303,715$ \\
Performing Arts Institutions & 547 & $38,928,713$ & 1361 & $60,975,373$ \\
\hline Total & 1922 & $63,403,985$ & 3149 & $123,279,088$ \\
\hline
\end{tabular}

\subsection{Managerial Drivers: Donation Patterns}

This section interprets the results of Art Bonus with reference to three aspects of the patterns of donation. These aspects should be useful in developing an effective managerial strategy for attracting financial resources for public cultural organizations. The results answer the following three questions: Who donates and at what level? Why is a donation made? What do patrons finance?

\subsubsection{Who Donates and at What Level?}

Data shows that most of the donations were made by individuals, which is in line with crowdfunding principles. In fact, out of a total of 3149 donations, 2093 were made by individuals $(66.5 \%), 887$ were made by companies $(28.2 \%)$, 94 were made by nonprofit organizations (3\%), and 75 were made by banking foundations (2.4\%) (Figure 3). 


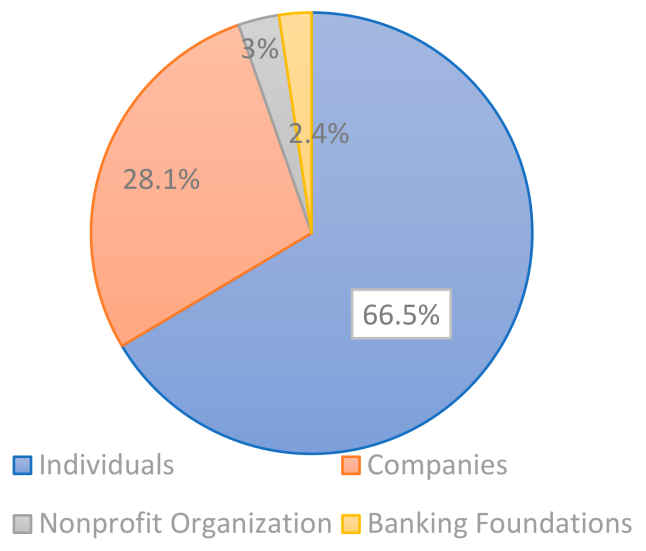

Figure 3. Number of donations/transactions made based on the donor's typology.

These percentages are similar in the three areas of Art Bonus, as shown in Table 2.

Table 2. Donations made to cultural heritage and performing arts institutions.

\begin{tabular}{ccccccc}
\hline & \multicolumn{2}{c}{ Cultural Heritage Institutions } & \multicolumn{3}{c}{ Performing Arts Institutions } \\
\cline { 2 - 7 } & $\begin{array}{c}\text { No. of } \\
\text { Donations }\end{array}$ & $\begin{array}{c}\text { Amount } \\
\text { Donated }(\boldsymbol{\epsilon})\end{array}$ & $\begin{array}{c}\text { Average } \\
\text { Donation }(\boldsymbol{(})\end{array}$ & $\begin{array}{c}\text { No. of } \\
\text { Donations }\end{array}$ & $\begin{array}{c}\text { Amount } \\
\text { Donated (€) }\end{array}$ & $\begin{array}{c}\text { Average } \\
\text { Donation }(\boldsymbol{(})\end{array}$ \\
\hline Individuals & 1227 & $3,148,747$ & 2566 & 866 & $3,458,764$ & 3994 \\
Corporates & 661 & $59,154,968$ & 89,493 & 495 & $57,498,610$ & 116,159 \\
\hline Total & 1788 & $62,303,715$ & 34,845 & 1361 & $60,957,373$ & 44,789 \\
\hline
\end{tabular}

However, focusing on the amount donated provides a different picture. In terms of total amounts, as shown in Figure 3, donations from individuals accounted for only $5.4 \%$ of all the funds received by cultural organizations $(€ 6,607,511)$. The highest amounts were donated by organizations, particularly companies $(€ 59,987,524)$, banking foundations $(€ 37,607,352)$, and nonprofit organizations $(€ 123,261,089)$. Figure 4 shows the amounts donated for the three areas.

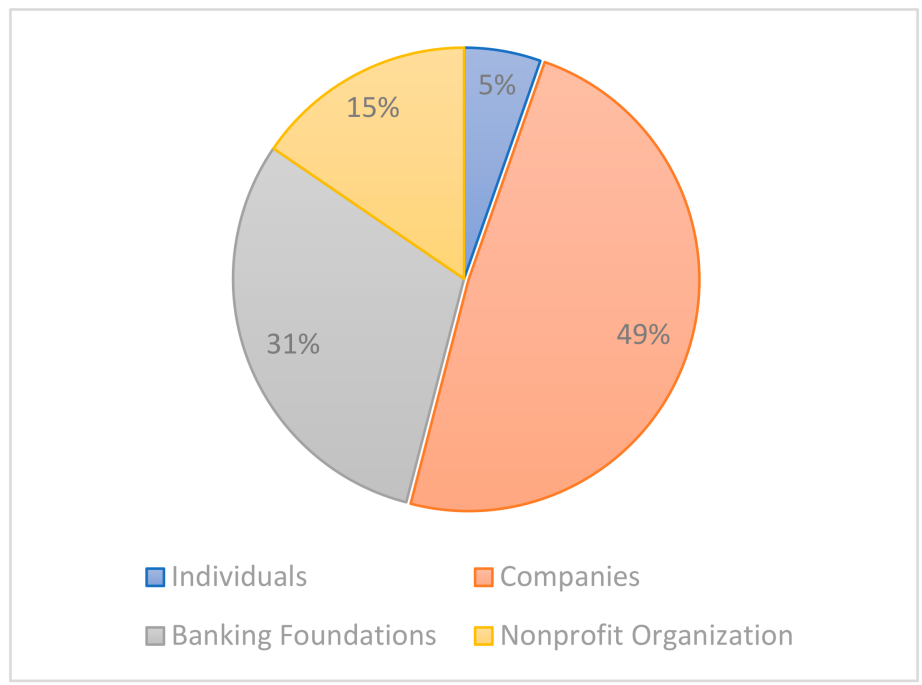

Figure 4. Amount of donations made by donor's typology. 
It is also noticeable that of 69 completed fundraising campaigns, 59 were supported by the contribution of a single donor (78.2\%), and in $83.3 \%$ of cases, this donor was an organization. Moreover, only $8.7 \%$ of the fundraising campaigns were supported by more than three donors.

The group of corporate donors consists of private companies, nonprofit organizations, and banking foundations. As shown in Table 3, a more detailed analysis revealed that banking foundations were the most important patrons for cultural heritage, overall donating $€ 37,607,351$ (mean donation of $€ 826,385$ ). Funding was provided mainly for the conservation and enhancement of historic buildings and archaeological sites, with private companies giving $€ 27,191,016$ (mean donation of $€ 58,728$ ) and nonprofit organizations donating $€ 1,387,698$ (mean of $€ 22,749$ ). Among the performing arts institutions, the major patrons were private companies ( $€ 32,796,508$; mean donation of $€ 77,350)$, followed by nonprofit organizations $(€ 17,671,004$; mean of $€ 535,485)$ and banking foundations $(€ 7,031,097$; mean of $€ 185,029)$.

Table 3. Amount donated based on donor type.

\begin{tabular}{|c|c|c|c|c|}
\hline & \multicolumn{2}{|c|}{ Area $A+$ Area $C$} & \multicolumn{2}{|c|}{ Area B } \\
\hline & $€$ & $\%$ & $€$ & $\%$ \\
\hline Individuals & $6,241,894$ & $10 \%$ & $3,458,764$ & $5.7 \%$ \\
\hline Companies & $27,191,016$ & $42 \%$ & $32,796,508$ & $53.8 \%$ \\
\hline Nonprofit organizations & $1,387,698$ & $2 \%$ & $17,671,004$ & $29.0 \%$ \\
\hline Banking foundations & $30,576,254$ & $47 \%$ & $7,031,097$ & $11.5 \%$ \\
\hline Total & $65,396,862$ & $100 \%$ & $60,957,373$ & $100 \%$ \\
\hline
\end{tabular}

\subsubsection{Why Is a Donation Made?}

An issue that is very important for management is knowing why donations are made. We investigated the relationship between the address of the donating organization and the address of the recipient. Here, the focus was on organizations (companies, nonprofit organizations, banking foundations) given that organizations accounted for $94.6 \%$ of the funds donated and that it is not always possible to determine the addresses of individuals.

As shown in Figure 5, data show that $85.4 \%$ of organizations made donations to cultural institutions located in the same province, representing $82.7 \%$ of the total donations. This relationship is even stronger for regions: $8.7 \%$ of the organizations made donations in their home region, representing $3.4 \%$ of the total value of the donations. Thus, only $5.8 \%$ of donations, or $13.9 \%$ of the donated resources, come from outside the region. However, organizations that make donations outside their region tend to be large companies or banks, which have branches in different regions and are known throughout Italy.

The data seems to confirm that, for corporate and for private giving, the main motives for donating are a sense of belonging to the community and a desire to support cultural institutions operating in their own area. This could explain the strong regional disparities between the different geographical areas of Italy, given the different levels of industrialization and localization of manufacturing firms and banking foundations. This geographical disparity reflected a tendency that was also identified in previous years [85].

Of the donations to cultural organizations, $83.4 \%$ were made to organizations located in northern Italy, $14.9 \%$ were made to organizations located in central Italy, and 1.6\% were made to organizations located in southern Italy. Moreover, cultural organizations in northern Italy were more active and successful in their fundraising campaigns (52\% had established campaigns; mean income: $€ 259,353)$ than their counterparts in central Italy (38\%; mean: $€ 63,177)$ and southern Italy (10\%; mean: €25.671). Regional disparities were also observed in the number of patrons and the value of donations: $67.2 \%$ in northern Italy (mean donation: $€ 51,124), 30.1 \%$ in the central regions (mean: $€ 20,334$ ), and $2.7 \%$ in southern Italy (mean: $€ 24,708)$. 


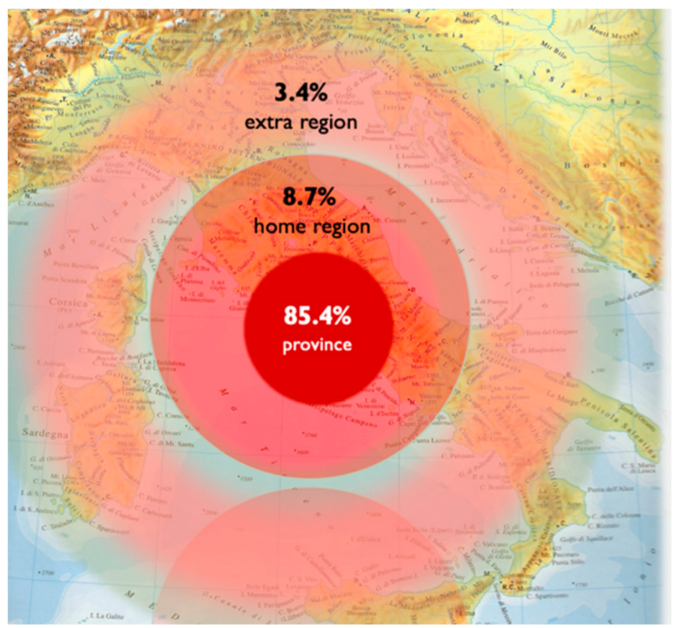

Figure 5. Donations by areas.

\subsubsection{What Do Patrons Finance?}

The last managerial issue is what patrons finance. Art Bonus makes it possible to finance either specific projects (Area A and Area C) or the activities of the cultural organization as a whole (Area B). Overall, cultural institutions received $€ 62,303,715$ in Area A and Area $C$ in comparison to $€ 60,957,373$ in Area B (+2.2\%). The data showed no great differences in either the number of donations made or in the type of donor (Table 4).

Table 4. What do patrons finance?

\begin{tabular}{|c|c|c|c|c|c|c|}
\hline & \multicolumn{3}{|c|}{ Areas A+ Area C } & \multicolumn{3}{|c|}{ Area B } \\
\hline & $\begin{array}{c}\text { No. of } \\
\text { Donations }\end{array}$ & $\begin{array}{c}\text { Amount } \\
\text { Donated }(€)\end{array}$ & $\begin{array}{c}\text { Average } \\
\text { Donation }(€)\end{array}$ & $\begin{array}{c}\text { No. of } \\
\text { Donations }\end{array}$ & $\begin{array}{c}\text { Amount } \\
\text { Donated }(€)\end{array}$ & $\begin{array}{c}\text { Average } \\
\text { Donation }(€)\end{array}$ \\
\hline Individuals & 1227 & $3,148,747$ & 2566 & 866 & $3,458,764$ & 3994 \\
\hline Companies & 463 & $27,191,016$ & 58,728 & 424 & $32,796,508$ & 77,350 \\
\hline Nonprofit organizations & 61 & $1,387,698$ & 22,749 & 33 & $17,671,004$ & 535,485 \\
\hline Banking foundations & 37 & $30,576,254$ & 826,385 & 38 & $7,031,097$ & 185,029 \\
\hline Total & 1788 & $62,303,715$ & 34,845 & 1361 & $60,957,373$ & 44,789 \\
\hline
\end{tabular}

However, there is a clear difference between the average donations made by the different types of donors. In particular, individuals, corporations, and especially nonprofit organizations tended to support the overall activities of cultural organizations (Area B). In contrast, banking foundations mainly financed specific projects (Area A and Area C), as shown in Table 4.

The ability of cultural organizations to successfully close their fundraising campaigns is another interesting trend. Data show that 583 fundraising campaigns were launched in Area A and Area C, and 64 were completed (10.9\%). In Area B, 181 fundraising campaigns were launched, but only $5(2.8 \%)$ were successfully closed. In terms of resources received as a proportion of requirements, Area $\mathrm{A}$ and Area $\mathrm{C}$ were more effective than Area B. They succeeded in attracting $17.6 \%$ of their requirements, while Area B attracted only $5.3 \%$. Moreover, one last difference can be seen in the types of cultural assets funded. In Area $A$ and Area $C$, museums (38.4\%) and monuments (33.1\%) received the most funding (see Table 1). In Area B, $95.9 \%$ of donations were made to theatres.

\section{Discussion and Implications for Management}

The findings about the Art Bonus scheme presented above have three main implications for the implementation of crowdfunding campaigns in the arts and cultural sector, further suggesting how managers could take advantage of such opportunities as they play 
a key role in ensuring the sustainability of the crowdfunding platform [47]. First, Art Bonus, like other crowdfunding platforms, was shown to be very useful in raising the profile of fundraising through its website; because the platform is provided to cultural organizations free of charge, it represents a low-cost way to access capital for these organizations [47]. The website is accessible to anyone who intends to donate, and it allows the donor to check the amount of funding that is needed and being donated in real time.

This is an effective response to donors' demands for greater transparency and traceability of funding $[21,23]$. Indeed, management can use the website to make their organization more accountable to supporters, thus increasing the level of trust between the recipient and the donors, as well as promoting fundraising. The results showed the fundraising efforts were more effective in Area A and Area C, where funding is targeted to specific projects, in comparison to Area $\mathrm{B}$, where resources are allocated to the organization as a whole. This confirms the importance of accountability in encouraging donations [23,76]. The effectiveness of fundraising in Area $A$ and Area $C$ is reflected in the number of donations received $(+31 \%)$ and of the total amount donated $(+2.2 \%)$, as well as the number of fundraising campaigns completed $(11 \%$ vs. $3 \%)$ and resources received as a percentage of resources required $(18 \%$ vs. $5 \%)$. The effectiveness of the fundraising efforts in Area B is limited to theatres, which received $96 \%$ of the total resources allocated to this area. Therefore, it would seem that it would be useful for management to promote, outside the ministerial channel, external ways to report on how resources are used, especially in terms of taking actions that could be perceived as reinforcing the integrity of the organization and building trust with a potential audience [30]. For example, this could be done by publishing work-in-progress updates on their own websites or social networks or issuing newsletters with information on projects. This also reflects the trend of sponsorship practice in Italy, which is mainly used to find the resources (monetary or in-kind) needed to recover, restore, or maintain the country's historical and architectural heritage [15].

The crowdfunding platform set up by the Italian government has increased the visibility of single organizations, and the wider audience it reaches increases the number and amount of donations and differentiates the revenue sources. Thus, we can say that not only is the platform democratizing the pool of donors [18], but it is also providing new perspectives on fundraising activities, giving all public sector cultural organizations the same tool to develop campaigns, frame the beneficiaries, and, consequently, eliminate dilemmas related to fundraising ethics [67]. To summarize, the platform facilitates the fundraising efforts of small- and medium-sized organizations, which might not have the resources (such as a website) to increases their visibility.

Fundraising has traditionally been based on a small number of patrons making highvalue donations, whereas crowdfunding relies on small donations from a larger pool of donors, potentially worldwide [18]. The data obtained from the first two years in which the Art Bonus platform operated showed that over $90 \%$ of the total number of donations were made by private organizations. This implies that the reform has not yet realized its full potential. The platform is not effectively attracting financing "from the crowd". Although civic crowdfunding has the potential to promote fundraising on a collective level [47], this requires a tailor-made campaign specifically targeting small and individual donors.

Individual donors require full transparency and a higher level of engagement in the activities of the cultural organizations to which they are donating. Despite its potential, currently, Art Bonus does not facilitate enough real engagement or a closer relationship among donors and cultural organizations, and although it is a first step toward ensuring visibility for cultural organizations, individual managers still need to autonomously identify the mechanisms they can use to engage with and relate to their donors. The fact that $85 \%$ of donor companies chose not to be anonymous suggests that image is another important motive for donating. Here, the implication is that, in addition to displaying information on the Mibac webpage, management would be well-advised to give higher visibility to donors, perhaps on their own websites, on social media, and in advertisements bearing their donors' names. The final observation is that over $86 \%$ of donors donated in their own 
geographical area. Participation in and the links between cultural institutions and the local community are key elements in fundraising strategies $[15,70]$, which is in keeping with previous studies of tourism and leisure that show how local residents have emerged as an important group of potential funders [30]. Thus, management needs to activate donor participation, involvement, and trust in the activities of cultural organizations in order to attract potential investors.

In this regard, there is a high potential for small- and medium-sized organizations, located in peripheral areas that might struggle to attract private sponsorship and that are more interested in iconic heritage, to capitalize on their investment in visibility $[15,16]$. Currently, the web platform artbonus.gov.it does not provide for different levels of engagement with the community and communicating about activities, which might limit a funder's trust in the platform and projects [30]. However, it would be useful to include key donors in the decision-making processes; invite them to events and galas; offer them free gifts, members' privileges, and special reductions; and provide online activities. This might help to create a sense of shared ownership of the heritage. At the same time, this reality confirmed that the platform is not taking full advantage of the potentiality behind the concept of crowdfunding, which could necessitate transcending geographical boundaries to raise awareness through the use of information technologies [59] and not failing to grasp new opportunities for developing sustainable models of engaging with larger audiences [29].

Managers of cultural organizations need to use the platform and fiscal incentives in an integrated strategy, but they also need to refine a successful fundraising strategy based on the specific type of audience for their organization, matching the organizational mission [10]. Therefore, they need to provide tools to increase transparency and accountability and to plan tailored fundraising strategies. This does not necessarily only imply financial transparency to reduce the perceived risk for funders [29]; it also refers to data and information that help donors engage with an organization and also strengthen the organization's relationships and trust [30] with key stakeholders in the local area and potential visitors. The data showed that a small number of donors are often crucial for the success of a fundraising campaign. In fact, $91.3 \%$ of the funds that were raised during the period under study came from campaigns where donations were made by up to three donors. The implication for management is clear: even in times of "funding from the crowd," it is still extremely important to build close one-to-one relationships with the main local stakeholders, especially local companies and banking foundations.

\section{Conclusions}

The growing need for new forms of financial support for public cultural organizations, including private donations, has led to the implementation of various measures, including tax incentives, in a significant number of countries. The choice of tool, such as a tax credit or tax rebate, asset, or cash donation, tends to reflect the type of government and the traditional model of philanthropic giving in each country.

The Italian Art Bonus scheme is interesting because it not only introduced a tax credit for donations to the public cultural heritage, but it also implemented the first national civic crowdfunding platform aiming to connect potential donors with receiving institutions. In a country that has a historically low percentage of people and organizations that make donations coupled with high levels of bureaucracy, the introduction of a financing system derived from the private sector, the crowdfunding model, has proven to be an innovative method to foster the financial sustainability of the arts and culture sector. It has also helped guarantee the feasibility of the patterns of cultural and social sustainability, independent of financial supports linked to the logics of market and financial return, such as sponsorships and PPPs.

The integrated perspective of cultural management and cultural policy, proposed in this study, addresses three points that decision makers must consider to ensure an effective civic crowdfunding campaign: 
- The importance of engaging with members of the local community in which the cultural organization operates, which also increases the potential to reach a wider and international audience (this was not fully exploited in the case study discussed in this paper);

- The necessity of building a system of compensation, which can include recognition of the donations made by the donors on the website and acknowledgement of the donation that was made;

- The importance of establishing a flow of accountable communication between the organization and its donors and clearly stating how the money will be used and for what purpose.

As stated in Section 5, the data from the first two years in which Art Bonus was implemented shows that it has not fully met its potential. A wider and more complete exploitation of its potential could lead Italian cultural organizations, which have traditionally depended almost exclusively on public funding, to innovate their business models and strategies. At the same time, fostering donations as a revenue stream, in comparison to other forms of private financing, will enable organizations to avoid the risk of being too dependent on the logics of market and financial return.

In conclusion, in the field of fundraising, cultural policy and managerial strategy are closely connected. An organization's managers can implement effective long-term strategies only when those are supported by a policy framework. The introduction of a new system of financing is also one of the strongest drivers of change and innovation for public institutions, which, traditionally, have been conservative and less open to change. At the same time, fruitful cultural policy relies on the willingness and ability of individual managers to support it.

\section{Limitations and Future Research}

This study has some limitations. First, the research was limited to Italy, and factors such as the culture and traditions of a country can influence donations regardless of tax incentives and managerial efforts [90,91]. Broadly speaking, although investments of financial and other resources by public authorities and cultural organizations strengthen the role of culture and enrich society, the impact of fiscal policy and managerial implications varies from country to country. Despite this limitation, this study could be useful for other countries where the propensity to donate is traditionally low, and it offers useful insights on how to implement successful strategies to incentivize private donations to public heritage where public financing is limited or decreasing. The fact that Art Bonus applies exclusively to the public sector overcomes the limitations of previous studies on philanthropy, which have pointed out the potential effects of 'crowding out' in donations when organizations are publicly financed.

Second, the study only covered the first two years of the Art Bonus scheme, and although this was important in enabling a comparison with the situation before that time period, evaluating the trend of donations over a period of five years, for example, might result in different outcomes. A more positive scenario would be a higher level of donations, indicating that policy makers and management have been successful in developing the culture of donation. A less positive scenario would be a return to lower levels of interest after an initial impulse of generosity triggered by the reform.

Third, the study did not consider the strategies adopted by managers since Art Bonus was introduced. Thus, there is a need for further qualitative and quantitative studies to identify the strategies that single organizations use to attract funds and engage with their donors. Our data did not provide insights about crowdfunding campaigns that single organizations have implemented by taking advantage of the platform or have implemented independently. Consequently, single- or multiple-case studies could be particularly useful for investigating the factors that impact the success or failure of a strategy developed by a single organization. Moreover, a reflection on how the COVID-19 crisis has impacted these paths would potentially be very interesting. 
Additional research areas related to the topics addressed in this work could be considered in the future. The increase in private donations undoubtedly reflects other factors, such as a sense of belonging, personal motivation for donating, and intrinsic reasons for donating. As noted in the literature review, motivational studies dominate the field of fundraising. Future research could not only investigate which are the main motivations for donating and how the fiscal incentives interplay with the crowdfunding platform for both individual and corporate donors, but also evaluate if other external factors, such as the crowding-out effects in public financing, impact donations. Finally, the Art Bonus scheme has shown an increasing trend in donations since it was first implemented, as declared by the Italian Minister of Culture, Dario Franceschini, in 2021. It collected approximately $€ 435$ million in donations from a total of approximately 14,283 patrons, distributed as follows: 445 in 2014, 1815 in 2015, 2329 in 2016, 2880 in 2017, 3226 in 2018, 3508 in 2019, and 78 in 2020. What is relevant is the importance of establishing a flow of accountable communication between the organization and its donors, clearly stating how the money will be used and for what purpose. Further studies will need to investigate the donations from a longitudinal perspective to identify how the level of donations and the donors' profile and behaviors have changed.

Author Contributions: Conceptualization, C.C.D. and F.B.; Methodology, S.F. and C.C.D.; Validation, C.C.D., F.B., S.F. and I.M.; Formal Analysis, S.F. and C.C.D.; Investigation, C.C.D., F.B., S.F. and I.M.; Resources, I.M.; Data Curation, S.F.; Writing-Original Draft Preparation, C.C.D. and F.B.; Writing-Review and EDITING, C.C.D. and F.B.; Visualization, C.C.D. and S.F.; Supervision, C.C.D., F.B., S.F. and I.M.; Project Administration, C.C.D.; Funding Acquisition, I.M. All authors have read and agreed to the published version of the manuscript.

Funding: The authors received no financial support for the research, authorship, and/or publication of this article.

Institutional Review Board Statement: Not applicable.

Informed Consent Statement: Not applicable.

Data Availability Statement: Not applicable.

Acknowledgments: We would like to thank Carolina Botti, who is responsible for managing and promoting the 'Art Bonus' on behalf of the Ministry of Cultural Heritage and Tourism, for her valuable support in providing us with data not available on the website. Our sincere gratitude also goes to the attendees of the Sole 24 Ore Business School for their help in collecting the data. We would like to thanks the reviewers for their preciouses comments and we would like to thanks the participants of the 14th International Conference on Arts and Cultural Management (AIMAC) for their preciouses suggestion of an earlier version of this work.

Conflicts of Interest: The authors declared no potential conflicts of interest with respect to the research, authorship, and/or publication of this article.

\section{References}

1. Hager, M.; Rooney, P.; Pollak, T. How fundraising is carried out in US nonprofit organisations. Int. J. Nonprofit Volunt. Sect. Mark. 2002, 7, 311-324. [CrossRef]

2. Sargeant, A.; Shang, J. Fundraising Principles and Practice, 2nd ed.; Wiley: San Francisco, CA, USA, 2017.

3. Weisbrod, B.A.; Dominguez, N.D. Demand for collective goods in private nonprofit markets: Can fundraising expenditures help overcome free-rider behavior? J. Public Econ. 1986, 30, 83-96. [CrossRef]

4. Taylor-Gooby, P. The Double Crisis of the Welfare State. In The Double Crisis of the Welfare State and What We Can Do about It; Palgrave Macmillan: London, UK, 2013; pp. 1-25.

5. Rubio-Arostegui, J.A.; Villarroya, A. Patronage as a way out of crisis? The case of major cultural institutions in Spain. Cult. Trends 2021. [CrossRef]

6. Gruening, G. Origin and theoretical basis of new public management. Int. Public Manag. J. 2001, 4, 1-25. [CrossRef]

7. Hong, S.; Ryu, J. Crowdfunding public projects: Collaborative governance for achieving citizen co-funding of public goods. Gov. Inf. Q. 2019, 36, 145-153. [CrossRef]

8. Chong, D. Arts Management, 2nd ed.; Routledge: London, UK; New York, NY, USA, 2010. 
9. Colbert, F.; Ravanas, P. Marketing Culture and the Arts, 5th ed.; Carmelle and Rémi Marcoux Chair in Arts Management: Montreal, QC, Canada, 2018.

10. Herrero, M.; Kraemer, S. Fundraising as organisational knowing in practice: Evidence from the arts and higher education in the UK. Int. J. Nonprofit Volunt. Sect. Mark. 2020, 25, e1673. [CrossRef]

11. Zorloni, A. Designing a strategic framework to assess museum activities. Int. J. Arts Manag. 2012, 14, 31-47.

12. Throsby, D. Cultural sustainability. In A Handbook of Cultural Economics; Towse, R., Ed.; Edward Elgar: Cheltenham, UK, 2003; pp. 183-186.

13. Stylianou-Lambert, T.; Boukas, N.; Christodoulou-Yerali, M. Museums and cultural sustainability: Stakeholders, forces, and cultural policies. Int. J. Cult. Policy 2014, 20, 566-587. [CrossRef]

14. Froelich, K.A. Diversification of revenue strategies: Evolving resource dependence in nonprofit organizations. Nonprofit Volunt. Sect. Q. 1999, 28, 246-268. [CrossRef]

15. Dolores, L.; Macchiaroli, M.; De Mare, G. Sponsorship's Financial Sustainability for Cultural Conservation and Enhancement Strategies: An Innovative Model for Sponsees and Sponsors. Sustainability 2021, 13, 9070. [CrossRef]

16. Giannakopoulou, S.; Kaliampakos, D. Social transformations of cultural heritage: From benefaction to sponsoring: Evidence from mountain regions in Greece. J. Mt. Sci. 2020, 17, 1475-1490. [CrossRef]

17. Bekkers, R.; Wiepking, P. A Literature Review of Empirical Studies of Philanthropy: Eight Mechanisms That Drive Charitable Giving. Nonprofit Volunt. Sect. Q. 2011, 40, 924-973. [CrossRef]

18. Massi, M.; Mion Dalle Carbonare, P.; Turrini, A. Turning crowds into patrons: Democratizing fundraising in the arts and culture. In The Routledge Companion to Arts Management; Byrnes, W.J., Brkić, A., Eds.; Routledge: Oxfordshire, UK, 2019 ; pp. 409-424. ISBN 9781351030861.

19. Moir, L.; Taffler, R. Does corporate philanthropy exist?: Business giving to the arts in the UK. J. Bus. Ethics 2004, 54, 149-161. [CrossRef]

20. Gianecchini, M. Strategies and determinants of corporate support to the arts: Insights from the Italian context. Eur. Manag. J. 2020, 38, 308-318. [CrossRef]

21. Bertacchini, E.; Santagata, W.; Signorello, G. Individual giving to support cultural heritage. Int. J. Arts Manag. 2011, $13,41-55$.

22. Sneddon, J.N.; Evers, U.; Lee, J.A. Personal Values and Choice of Charitable Cause: An Exploration of Donors' Giving Behavior: Nonprofit Volunt. Sect. Q. 2020, 49, 803-826. [CrossRef]

23. Sargeant, A. Relationship fundraising: How to keep donors loyal. Nonprofit Manag. Leadersh. 2001, 12, 177-192. [CrossRef]

24. Van Slyke, D.M.; Brooks, A.C. Why do people give? New evidence and strategies for nonprofit managers. Am. Rev. Public Adm. 2005, 35, 199-222. [CrossRef]

25. Bönke, T.; Massarrat-Mashhadi, N.; Sielaff, C. Charitable giving in the German welfare state: Fiscal incentives and crowding out. Public Choice 2013, 154, 39-58. [CrossRef]

26. Caldwell, M.; Woodside, A.G. The Role of Cultural Capital in Performing Arts Patronage. Int. J. Arts Manag. 2003, 5, 34-50.

27. Hemels, S.; Goto, K. (Eds.) Tax Incentives for the Creative Industries; Springer: Berlin/Heidelberg, Germany, 2017.

28. Schuster, J.M. Tax Incentives in Cultural Policy. In Handbook of the Economics of Art and Culture; Elsevier: Amsterdam, The Netherlands, 2006; pp. 1253-1298.

29. Marchegiani, L. From Mecenatism to crowdfunding: Engagement and identification in cultural-creative projects. J. Herit. Tour. 2018, 13, 143-151. [CrossRef]

30. Kim, M.J.; Hall, C.M.; Kim, D.K. Why do investors participate in tourism incentive crowdfunding? The effects of attribution and trust on willingness to fund. J. Travel Tour. Mark. 2020, 37, 141-154. [CrossRef]

31. Bœuf, B.; Darveau, J.; Legoux, R. Financing creativity: Crowdfunding as a new approach for theatre projects. Int. J. Arts Manag. 2014, 16, 33-48.

32. Flanigan, S.T. Crowdfunding and Diaspora Philanthropy: An Integration of the Literature and Major Concepts. Voluntas 2017, 28, 492-509. [CrossRef]

33. Maehle, N.; Otte, P.P.; Drozdova, N. Crowdfunding Sustainability. In Advances in Crowdfunding; Shneor, R., Zhao, L., Flåten, B.-T., Eds.; Palgrave Macmillan: Cham, Switzerland, 2020; pp. 393-422.

34. Messeni Petruzzelli, A.; Natalicchio, A.; Panniello, U.; Roma, P. Understanding the crowdfunding phenomenon and its implications for sustainability. Technol. Forecast. Soc. Change 2019, 141, 138-148. [CrossRef]

35. Stiver, A.; Barroca, L.; Minocha, S.; Richards, M.; Roberts, D. Civic crowdfunding research: Challenges, opportunities, and future agenda. New Media Soc. 2015, 17, 249-271. [CrossRef]

36. Yin, R.K. Case study research and application. Design and methods, 6th ed.; Sage: Thousand Oaks, CA, USA, 2018

37. Davies, R. Three provocations for civic crowdfunding. Inform. Commun. Soc. 2015, 18, 342-355. [CrossRef]

38. Llewellyn, S.; Tappin, E. Strategy in the public sector: Management in the wilderness. J. Manag. Stud. 2003, 40, 955-982. [CrossRef]

39. Settembre Blundo, D.; García Muiña, F.E.; Fernández del Hoyo, A.P.; Riccardi, M.P.; Maramotti Politi, A.L. Sponsorship and patronage and beyond: PPP as an innovative practice in the management of cultural heritage. J. Cult. Herit. Manag. Sustain. Dev. 2017, 7, 147-163. [CrossRef]

40. Ventura, C.; Cassalia, G.; Spina, L. Della New models of Public-private Partnership in Cultural Heritage Sector: Sponsorships between Models and Traps. Procedia - Soc. Behav. Sci. 2016, 223, 257-264. [CrossRef] 
41. Campbell, D.; Slack, R. Corporate "philanthropy strategy" and "strategic philanthropy" some insights from voluntary disclosures in annual reports. Bus. Soc. 2008, 47, 187-212. [CrossRef]

42. Carroll, R.; Joulfaian, D. Taxes and corporate giving to charity. Public Financ. Rev. 2005, 33, 300-317. [CrossRef]

43. Johnson, M.S.; Garbarino, E. Customers of Performing Arts Organisations: Are Subscribers Different from Nonsubscribers? Int. J. Nonprofit Volunt. Sect. Mark. 2001, 6, 61-77. [CrossRef]

44. Botetzagias, I.; Koutiva, E. Financial Giving of Foundations and Businesses to Environmental NGOs: The Role of Grantee's Legitimacy. Voluntas 2014, 25, 281-306. [CrossRef]

45. Caldwell, N.D.; Roehrich, J.K.; George, G. Social Value Creation and Relational Coordination in Public-Private Collaborations. J. Manag. Stud. 2017, 54, 906-928. [CrossRef]

46. Wong, J.; Ortmann, A. Do Donors Care About the Price of Giving? A Review of the Evidence, with Some Theory to Organise It. Voluntas 2016, 27, 958-978. [CrossRef]

47. Ramos, J. Crowdfunding and the Role of Managers in Ensuring the Sustainability of Crowdfunding Platforms; Publications Office of the European Union: Luxembourg, 2014; ISBN 9789279377273.

48. Mulcahy, K.V. Cultural Patronage in Comparative Perspective: Public Support for the Arts in France, Germany, Norway, and Canada. J. Arts Manag. Law Soc. 1998, 27, 247-263. [CrossRef]

49. Cwi, D. Public support of the arts: Three arguments examined. J. Cult. Econ. 1980, 4, 39-62. [CrossRef]

50. Nichols, J.E. Fundraising in the USA and the United Kingdom: Comparing today with directions for tomorrow. Int. J. Nonprofit Volunt. Sect. Mark. 1997, 2, 148-153. [CrossRef]

51. Valančienè, L.; Jegelevičiūtè, S. Crowdfunding for creating value: Stakeholder approach. Procedia-Social Behav. Sci. 2014, 156, 599-604. [CrossRef]

52. Beldad, A.; Gosselt, J.; Hegner, S.; Leushuis, R. Generous But Not Morally Obliged? Determinants of Dutch and American Donors' Repeat Donation Intention (REPDON). Voluntas 2015, 26, 442-465. [CrossRef]

53. Castles, F.G. The future of the Welfare State. Crisis Myths and Crisis Realities; Oxford University Press: Oxford, UK, 2004.

54. Mulcahy, K.V. Entrepreneurship or cultural Darwinism? Privatization and American cultural patronage. J. Arts Manag. Law, Soc. 2003, 33, 165-184. [CrossRef]

55. Simon, J.; Dale, H.; Chisolm, L. The Federal Tax Treatment of Charitable Organizations. In The Nonprofit Sector: A Research Handbook; Powell, W.W., Steinberg, R., Eds.; Yale University Press: New Haven, CT, USA, 2006; pp. 267-306.

56. Dehne, A.; Friedrich, P.; Nam, C.W.; Parsche, R. Taxation of nonprofit associations in an international comparison. Nonprofit Volunt. Sect. Q. 2008, 37, 709-729. [CrossRef]

57. Wiepking, P.; Handy, F. The Palgrave Handbook of Global Philanthropy; Palgrave Macmillan: London, UK, 2015; ISBN 978-1-137-55584-7

58. Lee, C.H.; Zhao, J.L.; Hassna, G. Government-incentivized crowdfunding for one-belt, one-road enterprises: Design and research issues. Financ. Innov. 2016, 2, 1-14. [CrossRef]

59. Moon, Y.; Hwang, J. Crowdfunding as an Alternative Means for Funding Sustainable Appropriate Technology: Acceptance Determinants of Backers. Sustainability 2018, 10, 1456. [CrossRef]

60. Dollani, A.; Lerario, A.; Maiellaro, N. Sustaining cultural and natural heritage in Albania. Sustainability 2016, 8, 792. [CrossRef]

61. Morduch, J. The microfinance promise. J. Econ. Lit. 1999, 37, 1569-1614. [CrossRef]

62. Poetz, M.K.; Schreier, M. The value of crowdsourcing: Can users really compete with professionals in generating new product ideas? J. Prod. Innov. Manag. 2012, 29, 245-256. [CrossRef]

63. Mollick, E. The dynamics of crowdfunding: An exploratory study. J. Bus. Ventur. 2014, 29, 1-16. [CrossRef]

64. Drucker, P.F. The new pluralism. Lead. Lead. 1999, 1999, 18-23. [CrossRef]

65. Sokka, S.; Badia, F.; Kangas, A.; Donato, F. Governance of cultural heritage: Towards participatory approaches. Eur. J. Cult. Manag. Policy 2021, 11, 4-19.

66. McCaskill, J.R.; Harrington, J.R. Revenue Sources and Social Media Engagement Among Environmentally Focused Nonprofits. J Public Nonprofit Aff. 2017, 3, 309-319. [CrossRef]

67. MacQuillin, I.; Sargeant, A. Fundraising Ethics: A Rights-Balancing Approach. J. Bus. Ethics 2019, 160, 239-250. [CrossRef]

68. Chirisa, I.; Mukarwi, L.; Rajab Mutamanda, A. Prospects and Options for Sustainable and Inclusive Crowdfunding in African Cities. In Crowdfunding and Sustainable Urban Development in Emerging Economies; Benna, U.G., Benna, A.U., Eds.; IGI Global: Hershey, PA, USA, 2018; pp. 211-231.

69. Kappel, T. Ex ante crowdfunding and the recording industry: A model for the U.S. Loyola of Los Angeles. Entertain. Law Rev. 2009, 29, 375-385.

70. Ishida, Y.; Okuyama, N. Local Charitable Giving and Civil Society Organizations in Japan. Voluntas 2015, 26, 1164-1188. [CrossRef]

71. Bray, I. Effective Fundraising for Nonprofits: Real-World Strategies That Work; Nolo: Berkeley, CA, USA, 2016 ; ISBN 1413322999.

72. Swanson, S.R.; Davis, J.C. Arts Patronage: A Social Identity Perspective. J. Mark. Theory Pract. 2006, 14, 125-138. [CrossRef]

73. Wiggins Johnson, J.; Ellis, B. The influence of messages and benefits on donors' attributed motivations: Findings of a study with 14 American performing arts presenters. Int. J. Arts Manag. 2011, 13, 4-15.

74. Young, D.R. The Prospective Role of Economic Stakeholders in the Governance of Nonprofit Organizations. Voluntas 2011, 22, 566-586. [CrossRef]

75. Cordery, C.J.; Baskerville, R.F. Charity Transgressions, Trust and Accountability. Voluntas 2011, 22, 197-213. [CrossRef] 
76. Neumayr, M.; Handy, F. Charitable Giving: What Influences Donors' Choice Among Different Causes? Voluntas 2019, 30, 783-799. [CrossRef]

77. Jordan, R.R.; Quynn, K.L. Planned Giving: A Guide to Fundraising and Philanthropy; John Wiley \& Sons: Hoboken, NJ, USA, 2009; ISBN 0470480823

78. Sargeant, A.; Hudson, J.; Wilson, S. Donor Complaints About Fundraising: What Are They and Why Should We Care? Voluntas 2012, 23, 791-807. [CrossRef]

79. von Selasinsky, C.; Lutz, E. The Effects of Pro-Social and Pro-Environmental Orientation on Crowdfunding Performance Sustainability 2021, 13, 6064. [CrossRef]

80. Zvilichovsky, D.; Inbar, Y.; Barzilay, O. Playing both sides of the market: Success and reciprocity on crowdfunding platforms. SSRN Res. Pap. 2015, 1-45. [CrossRef]

81. Scapens, R.W. Doing Case Study Research. In The Real Life Guide to Accounting Research. A Behind-the-Scenes View of Using Qualitative Research Methods; Humphrey, C., Lee, B., Eds.; Elsevier: Oxford, UK, 2004; pp. 257-279.

82. Merriam, S.B. Qualitative Research and Case Study Applications in Education. Revised and Expanded from "Case Study Research in Education"; ERIC: Washington, DC, USA, 1998; ISBN 0787910090.

83. UNESCO-UIS 2009 UNESCO Framework For Cultural Statistics; UNESCO Institute for Statistics: Montreal, QC, Canada, 2009; ISBN 9789291890750.

84. Associazione Civita Donare si può? Gli italiani e il mecenatismo culturale diffuso; Associazione Civita: Milano, Italy, 2009.

85. European Union (EU); Institute for International Relations (IMO). Encouraging Private Investment in the Cultural Sector; European Parliament: Brussels, Belgium, 2011.

86. Anderson, E.; de Mille, A. Fundraising for Museums. AIM Focus Pap. 2006, pp. 1-8. Available online: https://silo.tips/download/ fundraising-for-museums (accessed on 30 November 2021).

87. Ranganathan, S.K.; Henley, W.H. Determinants of charitable donation intentions: A structural equation model. Int. J. Nonprofit Volunt. Sect. Mark. 2008, 13, 1-11. [CrossRef]

88. Donelli, C.C.; Rentschler, R.; Fanelli, S. Value co-creation in non-profit organisations: The evolution of philanthropic strategies as entrepreneurial activities. In Proceedings of the EURAM 2018 (European Academy of Management) Conference, University of Iceland, Reykjavík, Iceland, 19-22 June 2018. Conference proceedings 2018.

89. Fanelli, S.; Donelli, C.C.; Zangrandi, A.; Mozzoni, I. Balancing artistic and financial performance: Is collaborative governance the answer? Int. J. Public Sect. Manag. 2020, 33, 78-93. [CrossRef]

90. Bennett, R. Corporate philanthropy in France, Germany and the UK: International comparisons of commercial orientation towards company giving in European nations. Int. Mark. Rev. 1998, 15, 458-475. [CrossRef]

91. Wright, K. Generosity vs. altruism: Philanthropy and charity in the United States and United Kingdom. Volunt. Int. J. Volunt. Nonprofit Organ. 2001, 12, 399-416. [CrossRef] 